\title{
Prevalência De Hipertensão Arterial Sistêmica E Diabetes Mellitus Em Pacientes Cirróticos Atendidos Em Ambulatório.
}

\author{
Porto, M.; Mattos, A.A.; John, J.A.; Miozzo, S.A.S.; Comerlato, P.H.; Silva, \\ R.R.; Contiero, P.; \\ Apresentador: Mariana Porto
}

\section{Resumo}

Introdução: É importante conhecer o perfil dos pacientes com cirrose, incluindo suas comorbidades. Entretanto, os trabalhos que avaliam esta população em nível ambulatorial são escassos na literatura em nosso país. O objetivo deste estudo é avaliar a frequência de hipertensão arterial sistêmica (HAS) e diabetes mellitus (DM) em pacientes de um ambulatório de hipertensão portal de um hospital terciário, de acordo com a etiologia da cirrose. Métodos:

Foi realizado um estudo coorte, observacional e retrospectivo em todos pacientes com diagnóstico de cirrose com acompanhamento em ambulatório entre março de 2005 a março de 2010 por meio de revisão de prontuários. Foram incluídos todos os pacientes com diagnóstico de cirrose e seguimento mínimo de um ano. Foram excluídos casos de co-infecção com HIV, transplante de órgãos prévio, diagnóstico de carcinoma hepatocelular avançado no primeiro atendimento, ausência de registro e perda de seguimento. Critérios para etiologias: Vírus C (VHC) - anti-HCV + PCR; Vírus B (VHB) - HBsAg + PCR; álcool - ingestão $>80 \mathrm{~g} / \mathrm{d}$ por 10 anos (homens) ou $40 \mathrm{~g}$ (mulheres); outros - diagnóstico histológico ou por exclusão. O projeto foi aprovado pelo CEP institucional. Na comparação de variáveis categóricas utilizou-se o teste do qui-quadrado. O nível de significância do estudo foi de $?=0,05$. Os dados foram analisados com o programa SPSS 18.0.

\section{Referência:}

Porto, M.; Mattos, A.A.; John, J.A.; Miozzo, S.A.S.; Comerlato, P.H.; Silva, R.R.; Contiero, P.; Prevalência De Hipertensão Arterial Sistêmica E Diabetes Mellitus Em Pacientes Cirróticos Atendidos Em Ambulatório.. In: II Congresso Brasileiro de Medicina Hospitalar - II CBMH [= Blucher Medical Proceedings, vol.1, num.5] São Paulo: Editora Blucher, 2014. p.51 DOI 10.5151/medpro-II-cbmh-046 